\title{
A Review on Reinforcement Corrosion Mechanism and Measurement Methods in Concrete
}

\author{
Suvash Chandra Paul ${ }^{1 *}$ and Adewumi John Babafemi ${ }^{2}$ \\ ${ }^{1}$ Discipline of Civil Engineering, School of Engineering, Monash University Malaysia, Malaysia \\ ${ }^{2}$ Department of Building, Faculty of Environmental Design and Management, Obafemi Awolowo University, Nigeria
}

Submission: April 6, 2018; Published: June 08, 2018

*Corresponding author: Suvash Chandra Paul, Discipline of Civil Engineering, School of Engineering, Monash University Malaysia, Jalan Lagoon Selatan, Bandar Sunway, 47500 Subang Jaya, Selangor, Malaysia, Email: suvash.chandra@monash.edu

\begin{abstract}
In reinforced concrete structure (RCS), one of the major durability problems occur due to the corrosion of embedded steel bar. Typically, the matrix properties surrounding the steel/concrete interface influence the corrosion of steel. Corrosion of steel will not happen in the presence of chloride and carbonation unless other contributing aggressive substances enter the concrete. For instance, the carbonation process mostly affects the concrete microstructure, which is not generally harmful. Also, chloride and carbonation cannot impair the integrity of concrete. However, concrete integrity may be considered to have been impaired once chloride ingress and/or carbonation occur, as the potential for corrosion then arises. Some acid and aggressive ions such as sulphate destroy concrete integrity and subsequently allow chloride, carbon dioxide and oxygen ingress, and the corrosion problem starts. Therefore, the aim of this paper is to describe the reinforcement corrosion mechanism in concrete and its measurement methods. Finally, this review paper may help researchers and designers to understand the corrosion mechanism in concrete and availability of their proper measurement methods.
\end{abstract}

Keywords: Corrosion rate; Micro-cell corrosion; Macro-cell corrosion; Passive film; Half-cell potential; Polarization resistance

Abbreviations: RCS: Reinforced Concrete Structure; FRC: Fibre Reinforced Concretes; RH: Relative Humidity; HCP: Half-Cell Potential; SCE: Silver Chloride Electrode; DC: Direct Current; RE: Reference Electrode; CE: Counter Electrode; GE: Guard Electrode; WE: Working Electrode; PPC: Potentiodynamic Polarization Curves; EIS: Electrochemical Impedance Spectroscopy; GPT: Galvanostatic Pulse Technique

\section{Introduction}

Once concrete was thought of as a durable material needing little repair throughout its lifetime. This hypothesis is correct indeed, except when the environment surrounding concrete is highly hostile and beyond its performance level [1]. In the last few decades, global warming has changed the earth's climate, ultimately influencing the performance of materials as well as of whole structures [2]. Inconsistency in the environment has brought to attention the influence thereof in numerous fields and many studies have been carried out to find the proper solution. Also the harsh environments e.g. in coastal areas, the practice of de-icing, industrial gases, etc. are usually causes for deterioration such as carbonation, corrosion, etc. As a result, some structures built more than 40-50 years ago have already deteriorated in many countries and about $50 \%$ of construction expenditure in developed countries is spent on repairs and maintenance [3].

Corrosion is a radical destructive process which takes place in a material, causing the material to deteriorate progressively with time. The economic loss due to corrosion damage of highway bridge decks, motorways and other infrastructure is high in many countries. In the USA, it is reported that US \$300-400 million dollars per year is required for the renovation of bridges and car parks alone [4]. In the UK, $£ 500$ million is spent on concrete repair per year, while in China, the annual loss due to corrosion has reached 100 billion RMB [4]. Improving material performance against corrosion can, therefore, make significant savings over the service lifespan of infrastructures.

Typically, the corrosion of a material changes its internal environmental process, which is usually influenced by the external environment. During the lifespan of a material, it often experiences different types of corrosion, and the resistance of each material type is dependent on its internal structure and composition. Indeed, material corrosion is a very complex subject since all physical (external forces, temperature, water and cyclic dampness), chemical (presence of chloride and alkali aggregate reaction) and biological (fungi, micro-organisms and insects) changes influence the corrosion process. In this paper, 
the description of reinforcement corrosion mechanism and its measurement methods in concrete is presented.

\section{Corrosion Mechanism in Concrete}

In concrete, the corrosion of steel is an electrochemical process where current passes from one medium to another (anode to cathode) as in an electrical circuit. In the hydration process of cement in concrete, a highly alkaline (sodium and potassium hydroxide) environment $(12.5<\mathrm{pH}<14)$ is formed. However, lower $\mathrm{pH}$ and carbonation are causes of corrosion [5]. The lower the $\mathrm{pH}$, the lower the amount of chloride ions needed to promote corrosion in the steel bar. The alkaline environment in concrete, with a $\mathrm{pH}>12.5$, therefore helps in forming a thin protective layer, called a passive film on the surface of the steel. Typically, this passive film is composed of different degrees of hydrated iron oxide $\mathrm{Fe}^{2+}$ and $\mathrm{Fe}^{3+}$, and it is only a few nanometres thick. Usually, the passive film of steel is secure from any kind of mechanical damage [6]. The whole process of corrosion in the steel is called depassivation. The time for such process to lead to corrosion is referred to as the initiation period of corrosion of steel in concrete as it is illustrated in Figure 1. By providing good quality, less permeable concrete and higher cover depth, the initiation period can be increased in reinforced concrete structure (RCS) [7-9]. So, the resistivity of concrete is related to the severity of corrosion. Table 1 shows the limit of resistivity and the corresponding possible corrosion in concrete $[10,11]$.

Table 1: Relationship between corrosion rate, resistivity and severity in concrete.

\begin{tabular}{|c|c|c|c|}
\hline Severity & Resistivity of Concrete $(\mathbf{k} \boldsymbol{\Omega . c m})$ & \multicolumn{2}{|c|}{ Corrosion Rate $(\boldsymbol{\mu m} /$ year $)$} \\
\hline & Langford \& Broomfield [10] & Langford \& Broomfield [10] & Bertolini et al. [11] \\
\hline Low corrosion rate & $>20$ & Up to 2 & $02-$ Apr \\
\hline Low to moderate corrosion rate & Oct-20 & 02-Jun & 05 -Sep \\
\hline Moderate to high corrosion rate & $05-$-Oct & 06-Dec & Oct-49 \\
\hline Very high corrosion rate & $<5$ & $>12$ & $50-99$ \\
\hline
\end{tabular}

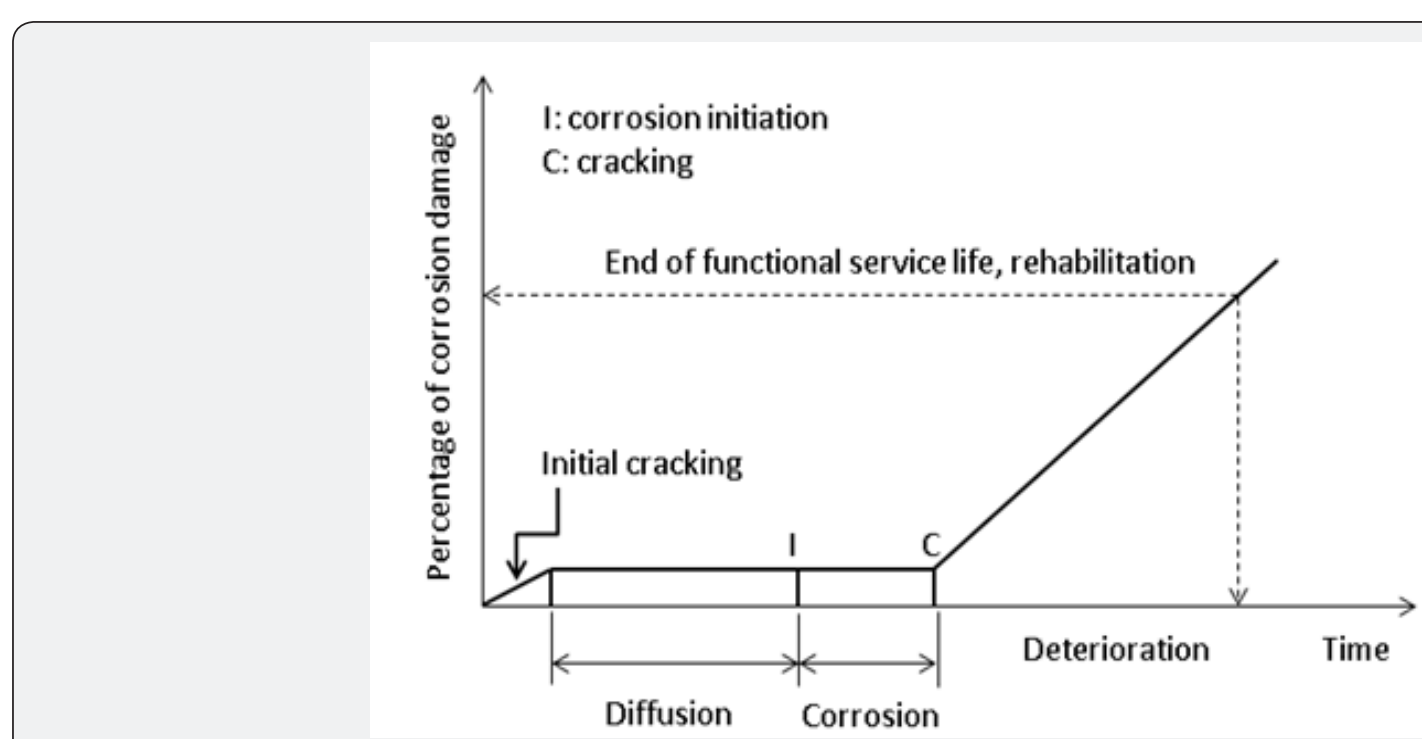

Figure 1: RCS service life prediction model schematisation [7].

\section{Initiation and propagation period}

A simple corrosion model developed by Tutti [12], which was later modified by Liu \& Weyers [7] with more graphical representation, is presented in Figure 1 . This model shows the different stages of the corrosion scenario in RCS. According to the Tutti model, the total service life of a RCS can be divided into two major phases:

i. The initiation period and

ii. The propagation period.

In the initiation period, carbonation and chloride ingress take place in the concrete as discussed in previous sections. The propagation period starts when the steel is fully depassivated and reaches a limiting state when corrosion is no longer acceptable. Water and oxygen must be present for corrosion to take place. In the absence of either water or oxygen, the corrosion process will not take place or will be very insignificant. Therefore, it can be said that the presence of wider cracks in concrete might reduce the service life of RCS since water, carbon and oxygen can easily penetrate the concrete and reach the steel.

\section{Mechanism of breaking passive film}

The passive film is the barrier that protects steel from corrosion, which can be influenced by the external environment as well as the steel substrate [13]. Typically, it forms from the 
cement hydration products which then create an interlocking network of discrete crystallites and bind the aggregate and the reinforcement together [14]. The process of depassivation of reinforcing steel in concrete is not yet clearly understood. This is because of its complexity and the many factors involved in the process. Typically, the passive film is a very thin layer and because it is inside the concrete, it makes it difficult to examine correctly. The hypothesis is that, when chloride comes into contact with the passive film, it reduces the resistance of the passive film [15]. However, in concrete, the contact between chloride and the passive film is not uniform and where it happens, an anodic region forms more rapidly and corrosion continues. On the other hand, the unaffected or remaining area of steel bar remains passive. Another hypothesis is that, chloride ions form a dissolvent compound with $\mathrm{Fe}^{2+}$ ions, and as a result, a passive film cannot form and the process encourages further metal corrosion [15].

\section{Micro-cell and macro-cell corrosion}

In any corrosion process, the steel surface is affected such that part of the steel acts as an anode and other adjacent parts act as the cathode. The corrosion rate in the steel is highly influenced by these two zones. Depending on their positions in the steel bar, corrosion can be classified as either micro-cell or macro-cell corrosion. The formation of micro-cell and macro-cell corrosion in cracked concrete is discussed below.

Micro-cell corrosion: When the distance between the anode and the cathode is very small or difficult to separate, it is called micro-cell corrosion [16]. So, in finely distributed cracks in concrete like some fibre reinforced concretes (FRCs), there is a big possibility of forming micro-cell corrosion. In this case, cracks act as a path for oxygen penetration to the cathode. Since the cathodic area is small, it is expected that there will be less damage in the RCS from this type of corrosion process $[17,18]$.
Macro-cell corrosion: In this case, the anode and cathode areas are far apart and the anode area is limited to the crack zone. Oxygen penetrates to the cathode part through the uncracked portion of concrete. Since the cathode area in the macro-cell corrosion process is much larger than in micro-cell corrosion, the corrosion rate due to macro-cells is also higher [19-21].

\section{Re-passivation of corrosion}

Once corrosion starts in the steel, it is not always certain that the corrosion rate will increase. Due to the complex electrochemical mechanism of steel corrosion in concrete, the rate of corrosion may decrease or stop [22]. Typically, when pitting corrosion takes place, current circulation in the anodic part incites and gradually increases the chloride content and acidity, so that propagation may take place even if the potential of the steel is reduced, e.g. owing to an external cathodic polarization. This activity is illustrated in Figure 2. It can be seen that the current growth replaced anodically during cyclic polarization in which the potential of the steel (by external polarization) is first raised above pitting potential $\left(E_{p i t}\right)$ to initiate localized attack and then lowered until conditions of passivity are established again. To stop the attack, it is necessary to reach a potential value, called the protection potential $\left(E_{\text {pro }}\right)$, which is more negative than $E_{p i t}$. Thus, the interval of the potential between $E_{p i t}$ and $E_{p r o}$ is characterized by the fact that it does not initiate the attack, but if the attack has already begun, it permits propagation of the attack. $E_{p r o}$ varies, as does $E_{\text {pit }}$, with the chloride level, $\mathrm{pH}$, and temperature [11]. Depending on the potential of steel and chloride content in the concrete, it is possible to define different domains where pitting corrosion can or cannot initiate and propagate, and other effects may take place [11]. This phenomenon can only be valid in chloride-induced corrosion since the localized pitting corrosion mostly occurs in a chloride-laden environment.

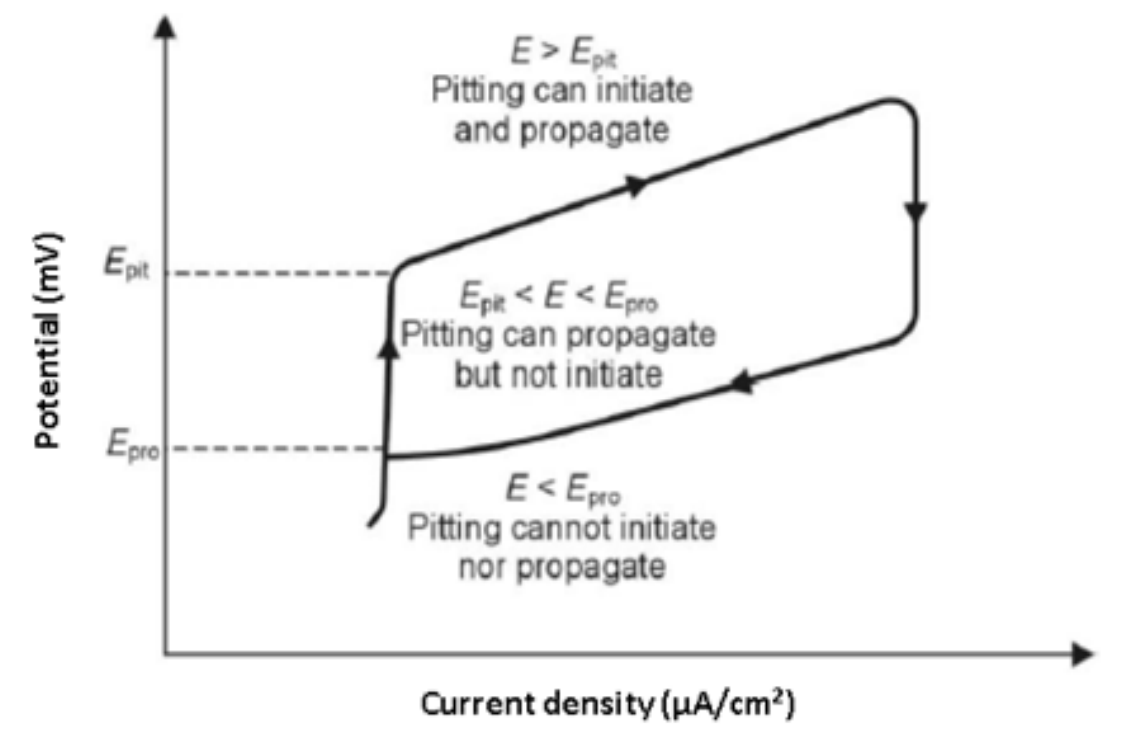

Figure 2: A representation of cyclic anode polarization curve of an active-passive material in chloride-laden environment [4]. 
Another reason for the reduction in corrosion rate may be due to the self-healing behaviour of materials [23,24]. Not many studies have been done on this issue since it is complicated by the formation of oxides, crack patterns and different chemical reactions. If self-healing can take place in concrete, it can also reduce the further penetration of chemical substances resulting in a lower rate of corrosion $[25,26]$. It has also been postulated that the steel bar interface with the surrounding cement-based matrix plays a significant role in corrosion protection. Experimental evidence has shown that a strong interface layer surrounding the steel increases the corrosion initiation period [27].

\section{Corrosion rate of steel}

The damage of steel in concrete is determined by the corrosion rate. Depending on the exposure type, the corrosion rate in RCS can vary from 2 to $100 \mu \mathrm{m} /$ year as the relative humidity (RH), $\mathrm{CO}_{2}$ and chloride concentration at the reinforcement level changes with time [28]. Corrosion rate also increases in more harsh exposure conditions. A higher corrosion rate can be observed in RCS in coastal regions as well as in structures where salt is used to dissolve ice such as bridge decks, motorways, etc., since the chloride concentration level in such structures is very high. Until now, the corrosion mechanism is not fully understood because many factors are involved. However, it is suggested that higher resistivity of concrete can lead to lowering the corrosion rate because when the reinforcing steel bar corrodes, electrons flow through the bar and ions flow through the concrete. The ion flow in concrete is controlled by the resistivity or electrical conductance of concrete and therefore, lower resistivity means a higher ion flow and as a result, higher corrosion is expected in concrete.

Factors influencing the corrosion rate: As previously mentioned, in a chloride-laden environment, when the amount of chloride reaches the threshold level, it creates an environment that damages the protective film of steel bars embedded in concrete. Many factors such as amount of moisture in concrete, steel surface area ratio at the anode and cathode area, concrete resistivity, humidity and temperature, etc. in concrete influence the corrosion rate of steel bars [29-31]. In the corrosion process, the presence of oxygen accelerates the corrosion rate of a steel bar. However, it also depends on the amount of moisture present in the concrete. If the concrete is fully saturated, the oxygen diffusion rate is lower because oxygen cannot diffuse through moisture. However, in dry concrete, oxygen can easily diffuse through pores or cracks in the concrete. It is found that the wetting and drying cycles of concrete accelerates the steel corrosion process [32]. In the wetting process, the presence of moisture in concrete acts as an electrolyte which causes lower resistivity of concrete than in the drying process. As a result, higher half-cell potential values can be found in concrete when it is in contact with moisture than when it is in a dry environment. A sufficient amount of oxygen is also necessary in the rapid corrosion process. Concentrated polarization occurs when there is not a sufficient amount of oxygen in the concrete for the cathodic reaction, and so the corrosion current is reduced [32].

Corrosion products: After corrosion initiation in reinforced concrete, steel corrosion propagates and produces expansive rust surrounding the steel bar (mainly ferrous and ferric hydroxide $\mathrm{Fe}(\mathrm{OH})_{2}$ and $\mathrm{Fe}(\mathrm{OH})_{3}$ ), that occupies a much larger volume than the original reinforcement and thereby generates radial stress in the surrounding concrete at the interface between the reinforcement and concrete. Figure 3 shows the corrosion products and their relative volumes. When the stress from these products exceeds the maximum tensile capacity of the concrete cover, the concrete cracks and may eventually spall off. This scenario is very common in RCS and it can also be observed visually [33].

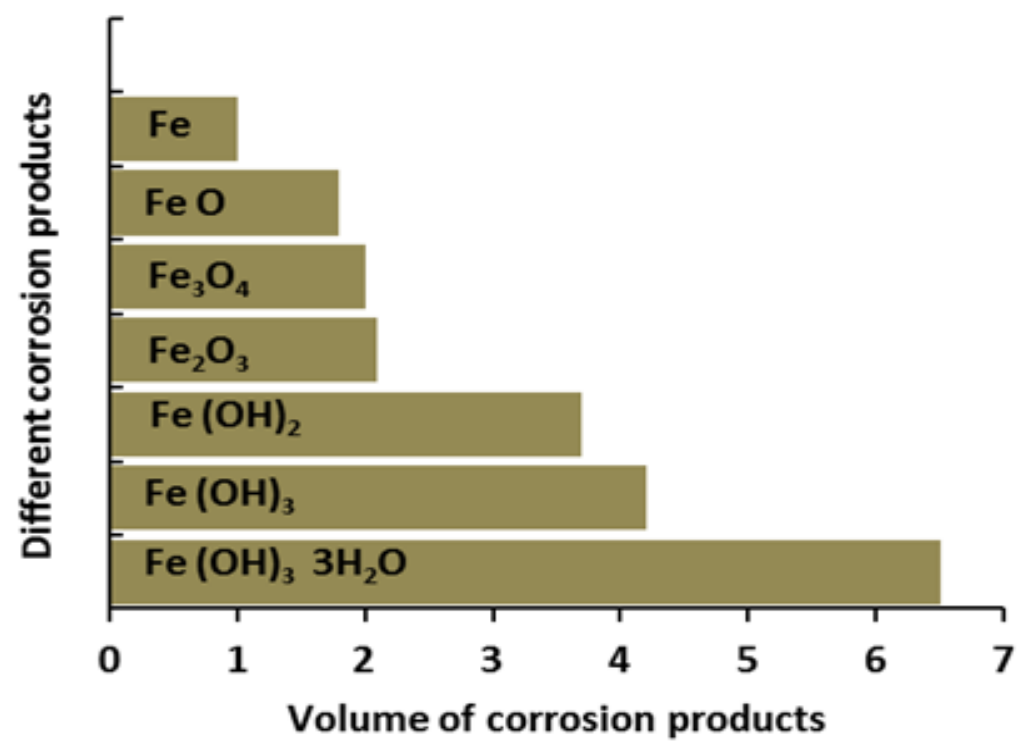

Figure 3: Different corrosion products and their volume [33]. 


\section{Civil Engineering Research Journal}

\section{Types of Corrosion}

Depending on the types of materials and their exposure conditions, different types of corrosion exist. The corrosion mechanism in different materials is also different since the element compositions are not the same. In the reinforcement within the concrete, different potential may exist in different places, which may form corrosion cells by continuous chemical processes that cause a flow of electrons or ions from one position to another. In electrochemical corrosion, the anode serves as an electrode which normally releases electrons while the cathode receives electrons. In both anodic and cathodic processes, the total load exchanged must be equal. Typically, the cathodic process is slower and the speed of corrosion is determined from this process [34]. Figure 4 shows the reactions that take place in the anode and cathode areas during the corrosion process. Some of the oxidations in different environments are shown below:
Oxygen reduction in aqueous environment:

$$
2 \mathrm{H}_{2} \mathrm{O}+\mathrm{O}_{2}+4 e \rightarrow 4 \mathrm{OH}^{-}
$$

Hydrogen reduction in acidic environment:

$$
2 \mathrm{H}^{+}+2 e \rightarrow 2 \mathrm{H} \rightarrow \mathrm{H}_{2}
$$

Metal oxidation in anode due to environmental reaction:

$$
\begin{gathered}
\mathrm{Me} \rightarrow \mathrm{Me}^{2+}+z e \\
\mathrm{Fe} \rightarrow \mathrm{Fe}^{2+}+2 e^{-} \\
2 \mathrm{H}_{2} \mathrm{O}+\mathrm{O}_{2}+4 e^{-} \rightarrow 4 \mathrm{OH}^{-} \\
\mathrm{Fe}^{2+} \rightarrow 2 \mathrm{OH}^{-} \rightarrow \mathrm{Fe}(\mathrm{OH})_{2} \\
4 \mathrm{Fe}(\mathrm{OH})_{2}+2 \mathrm{H}_{2} \mathrm{O}+\mathrm{O}_{2} \rightarrow 4 \mathrm{Fe}(\mathrm{OH})_{3}
\end{gathered}
$$

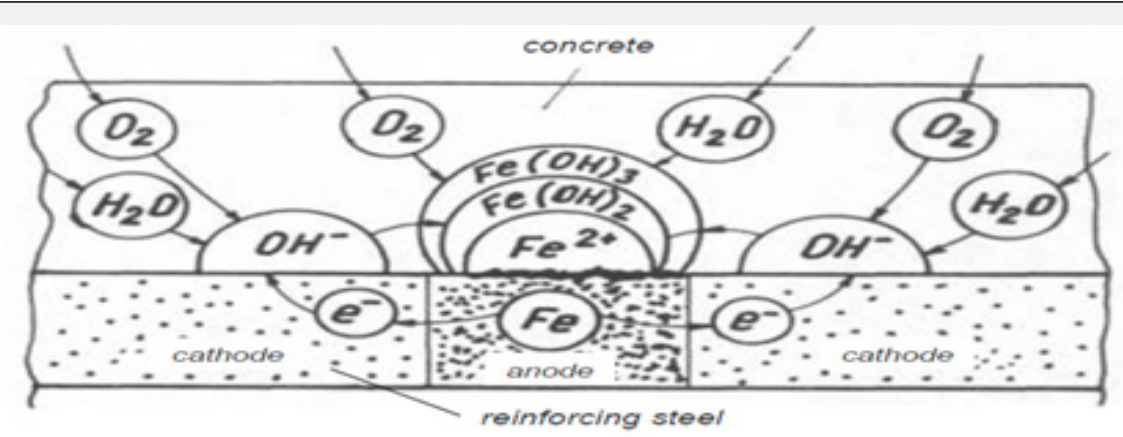

Figure 4: Formation of corrosion microcell in concrete [34].

The corrosion types can be classified in different ways based on the corrosion mechanism, final damage appearances, environment induced corrosion, etc. The classification of corrosion types is not absolute and the definition of corrosion type can only be applicable under certain conditions [35]. Corrosion types according to corrosion mechanisms are described in this section.

\section{Uniform corrosion}

When the distance between the anodic and cathodic areas is small, uniform corrosion is typically the effect. It is common in carbonated concrete structures since the carbonation of concrete normally proceeds in all the exposed areas of concrete structure, and the decrease of $\mathrm{pH}$ value would be expected over a relatively large area. Oxygen is also available over the exposed area. As a result, anodic and cathodic area may possibly be distributed over the rebar surface [35].

\section{Galvanic corrosion}

In reality, it is often impossible to form uniform corrosion over the whole length of rebar because of concrete heterogeneity. Depending on the exposure types, the cathodic process in most sites is stronger than the anodic process, while at some sites, anodic reaction can be faster than the cathodic reaction
[18]. Higher cathodic and anodic ratios will also produce more concentrated corrosion damage to the rebar. In large dimensioned concrete structures, galvanic corrosion plays an important role because of the fact that the oxygen, carbonation and chloride attack simultaneously and the possible breakdown of passive film is not constant over the total length of rebar [35].

\section{Localized corrosion}

The corrosion damage morphology can be referred to as the localized corrosion. It can also be classified as pitting or crevice corrosion. In this case, the anodic to cathodic are aratio is very small (localized corrosion), but the corrosion penetration rate in the anodic area is relatively higher [18]. Localized corrosion mostly happens due to the chloride attack in concrete on some particular sites. The chloride ions tend to accumulate in the affected/pit area and the $\mathrm{pH}$ of the solution decrease drastically. This leads to the environment in the pit area becoming aggressive and in turn, further accelerates the anodic dissolution of steel in the pits. The loss of rebar cross-section and strength is a major concern for pitting corrosion. Therefore, a relatively small amount of pitting corrosion can induce significant damage to the reinforcement [35] due to the localised damage and reduction of the cross-section. 
Methods of Corrosion Rate Determination in Concrete

Information regarding the corrosion rate of steel bars is an important parameter for the evaluation of the service life as well as the required repair pattern (extensive or normal) of any RCS. Measuring the real corrosion rate in steel is a difficult task. Currently, there are several methods to measure the corrosion potential and/or rate of steel in concrete and some of them are discussed in this section.

\section{Half-cell potential (HCP) method}

The half-cell potential (HCP) measuring technique is a standard method for the inspection of corrosion probability in RCS as set out by the American National Standards (ASTM C876). Typically, two types of half-cell, namely a copper-copper sulphate electrode (CSE) and a silver-silver chloride electrode (SCE) are used to measure the corrosion potential $\left(E_{\text {corr }}\right)$ in millivolt $(\mathrm{mV})$. The test is limited by the fact that a direct connection to the reinforcing steel has to be made. It is also only applicable to uncoated reinforcing steel imbedded in concrete where the surface has not been coated with a di-electric material. The halfcell is composed of an unreactive outer sleeve with a copper rod that is suspended in a saturated solution of copper sulphate. A saturated solution is maintained by ensuring that un-dissolved crystal copper sulphate is visible in the distilled water solution within the half-cell. The tip of the half-cell (also referred to as a reference electrode) is made of a porous material, normally wood or ceramic, which allows it to remain wet by capillary action. The half-cell is connected as illustrated in Figure 5 and a voltmeter is used to measure the potential difference between the steel and the reference electrode.

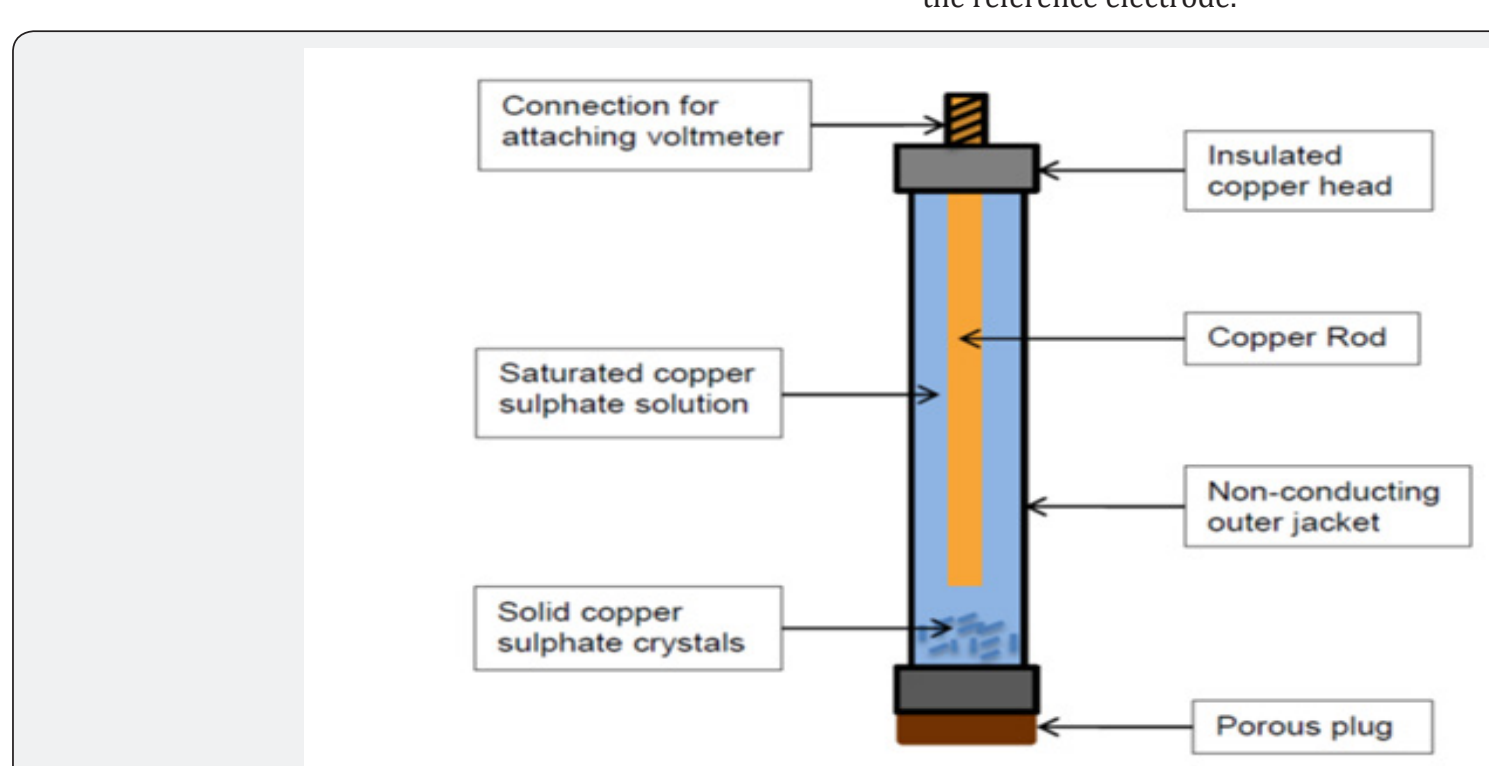

Figure 5: A representation of CSE half-cell with different components.

The potential value measured can only be used to give a general indication of the probability of corrosion activities. The measurements are interpreted according to Table 2. It must be noted that certain conditions may arise where potential readings will reflect values more negatively than - $350 \mathrm{mV}$ without having significant corrosion activity occurring. This may be as a result of a polarisation phenomenon created by limited oxygen diffusion. Concrete resistivity is dependent on matrix properties and the $\mathrm{HCP}$ reading is influenced by the resistivity.

Table 2: Corrosion condition related to half-cell potential [36].

\begin{tabular}{|c|c|c|}
\hline \multicolumn{2}{|c|}{ Corrosion Potential $\left(E_{\text {corr }}\right)$ Values } & $\begin{array}{c}\text { Corrosion Probability } \\
\text { (\%) }\end{array}$ \\
\hline (mV vs. SCE*) & (mV vs. CSE+) & \\
\hline$E_{\text {corr }}>-125$ & $E_{\text {corr }}>-200$ & 10 (low risk of corrosion) \\
\hline$-126 \leq E_{\text {corr }} \leq-275$ & $-200 \leq E_{\text {corr }} \leq-350$ & Intermediate \\
\hline$E_{\text {corr }}<-276$ & $E_{\text {corr }}<-350$ & $\begin{array}{c}90 \text { (high risk of } \\
\text { corrosion) }\end{array}$ \\
\hline$E_{\text {corr }}<-426$ & $E_{\text {corr }}<-500$ & Severe corrosion \\
\hline
\end{tabular}

Note: ${ }^{*} \mathrm{Ag} / \mathrm{AgCl}$ and $+\mathrm{Cu} / \mathrm{CuSO} 4$ half-cell
Factors influencing $\mathrm{HCP}$ reading: The $\mathrm{HCP}$ reading in concrete can be more negative/higher than the typical range of potential values recommended by the ASTM [36]. This is due to the fact that the polarisation phenomenon is significantly affected by the slow oxygen diffusion in concrete $[37,38]$. A study by $\mathrm{Gu}$ \& Beaudoin [38] summarized a number of factors influencing the HCP reading and suitability of following ASTM guidelines in determining the corrosion probability of steel in concrete as shown in Table 3.

Table 3: Effect of different factors on HCP readings and corrosion probability [38].

\begin{tabular}{|c|c|c|c|}
\hline Conditions & HCP reading & $\begin{array}{c}\text { Rate of } \\
\text { Corrosion in } \\
\text { Steel Bar }\end{array}$ & $\begin{array}{c}\text { Applicable to } \\
\text { ASTM C876 }\end{array}$ \\
\hline $\begin{array}{c}\text { Lower oxygen } \\
\text { increase }\end{array}$ & No negative \\
\hline $\begin{array}{c}\text { Carbonation/lower } \\
\mathrm{pH}\end{array}$ & to negative & increase & Yes \\
\hline Higher chloride & to negative & increase & Yes \\
\hline
\end{tabular}




\section{Civil Engineering Research Journal}

\begin{tabular}{|c|c|c|c|}
\hline $\begin{array}{l}\text { Anodic corrosion } \\
\text { inhibitor }\end{array}$ & to positive & decrease & Yes \\
\hline $\begin{array}{l}\text { Cathodic corrosion } \\
\text { inhibitor }\end{array}$ & to negative & decrease & No \\
\hline $\begin{array}{l}\text { Mixed corrosion } \\
\text { inhibitor }\end{array}$ & $\begin{array}{l}\text { to positive or } \\
\text { negative }\end{array}$ & decrease & No \\
\hline Epoxy-coated rebar & to positive & not related & No \\
\hline Galvanized rebar & to negative & not related & No \\
\hline Dense concrete cover & to negative & not related & No \\
\hline Concrete resistance & to positive & not related & No \\
\hline Dry concrete & to positive & not related & No \\
\hline Coating and sealers & to positive & not related & No \\
\hline Concrete repair patch & $\begin{array}{l}\text { to positive or } \\
\text { negative }\end{array}$ & not related & No \\
\hline
\end{tabular}

Various factors such as oxygen, corrosion inhibitors, carbonation, epoxy coating in steel, types of steel, concrete density, etc. significantly influence the HCP reading. Insufficient oxygen in concrete causes steel to become more active even if there is no sign of corrosion and as a result, a more negative potential value may be obtained in concrete from a half-cell reading. HCP value can also be influenced by the higher density of the concrete layer above reinforcing steel. Dense concrete provides a strong barrier against chloride reaching the steel as well as limiting oxygen diffusion. Typically, HCP readings are taken at a distance from the reinforcing steel, which is inside the concrete at a depth varying according to the designed cover depth. In this case, the obtained HCP readings are actually of mixed potential. This implies that the cathodic region influences the potential readings and hence, the readings are more negative than the actual potential near to the reinforcing steel [39]. Cusson \& Qian [40] concluded that if concrete permeability can be reduced, the oxygen level near the reinforcing steel will also be reduced and this may cause more negative HCP readings in the steel bar.

\section{Electrochemical corrosion test}

Corrosion behaviour in concrete is an electrochemical process, and therefore the potential and current due to reduction/oxidation of reinforcing steel can be measured by electrochemical testing. There are several possible ways in which these two variables can be measured, while all the techniques force a potential on the working electrode and measure the resulting current or vice versa. So, ultimately the corrosion process in RCS can be monitored by this technique without any destruction. It is due to the fact that all electrochemical tests follow some fundamental model of the electrode kinetics associated with corrosion processes to quantify corrosion rates. The magnification of the electrical signals created during these tests permits very precise and sensitive measurements to be carried out. Some of the electrochemical corrosion testing techniques are discussed in this section.

Polarization resistance technique: The polarisation resistance $\left(R_{p}\right)$ technique may be considered to be the most encompassing and attainable method of measuring the rate of corrosion in steel at present [11]. It has been used for nearly three decades with continuous improvements with respect to the accuracy of its application as found in literature over the years [41-43]. The method uses the measurement of the instantaneous corrosion current density $i_{\text {corr }}\left(\mu \mathrm{A} / \mathrm{cm}^{2}\right)$ to determine the rate of degradation of a concrete structure affected by corrosion. However, the method is limited since it cannot quantify the loss of steel cross-section but will be able to distinguish between areas of active and passive corrosion [43]. The free corrosion potential $\left(E_{c o r r}\right)$ as described previously and the electrical concrete resistance $\left(R_{e}\right)$ are used to validate and add to the reliability of the method.

The most accurate setup required to measure the $R_{p}$ effect is a so-called modulated guard ring technique [44]. The setup is an improvement of the direct current (DC) polarisation resistance measurement with ohmic drop that has been used since the 1970's. It comprises of a central reference electrode (RE) surrounded by two concentric electrodes, one acting as a counter electrode (CE) and the outer electrode as a guard electrode (GE). Figure 6 depicts the setup of the whole system. The steel reinforcing acts as the working electrode (WE) and is connected, with the other electrodes, to a potentiostat. The guard ring technique is further modulated by two reference electrodes between the CE and GE which help to control the polarisation of the electrodes and the concrete beneath them.

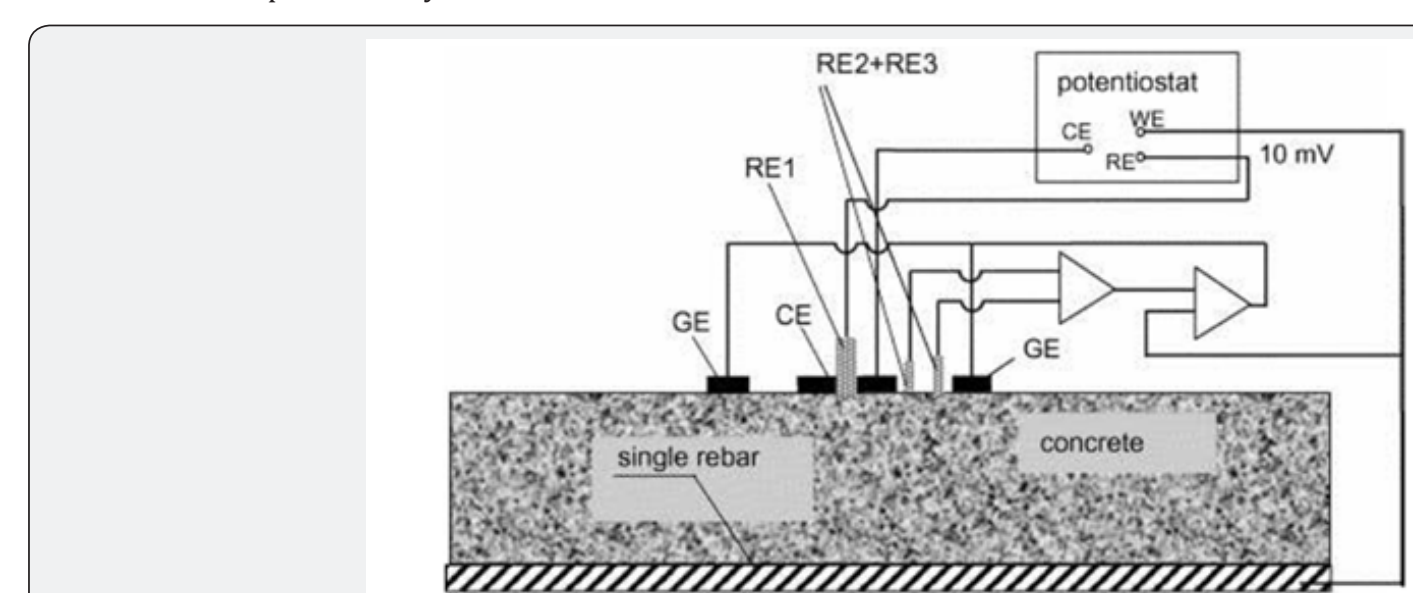

Figure 6: Modulated guard ring setup [44]. 


\section{Civil Engineering Research Journal}

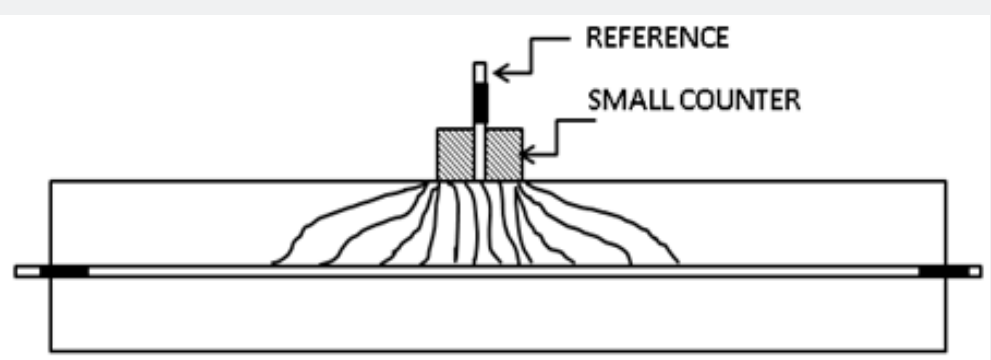

Figure 7: Non-uniform current distribution under small counter electrode [43].

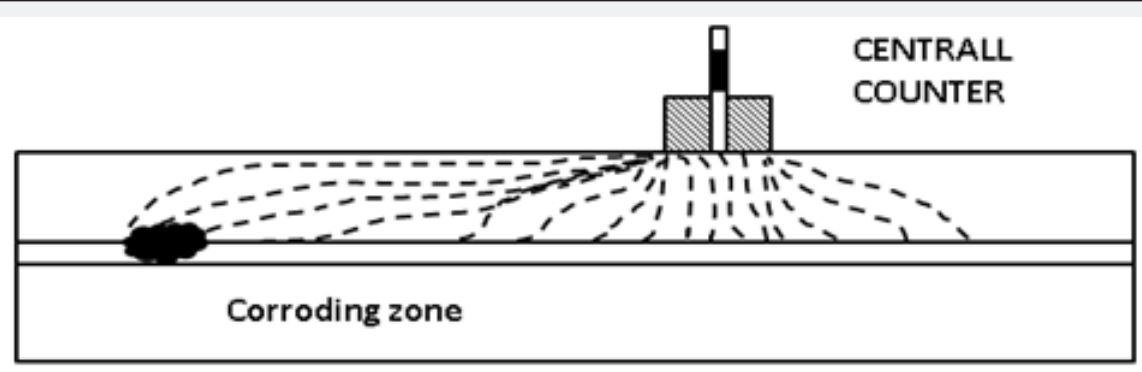

Figure 8: Effect of localised corrosion [43].

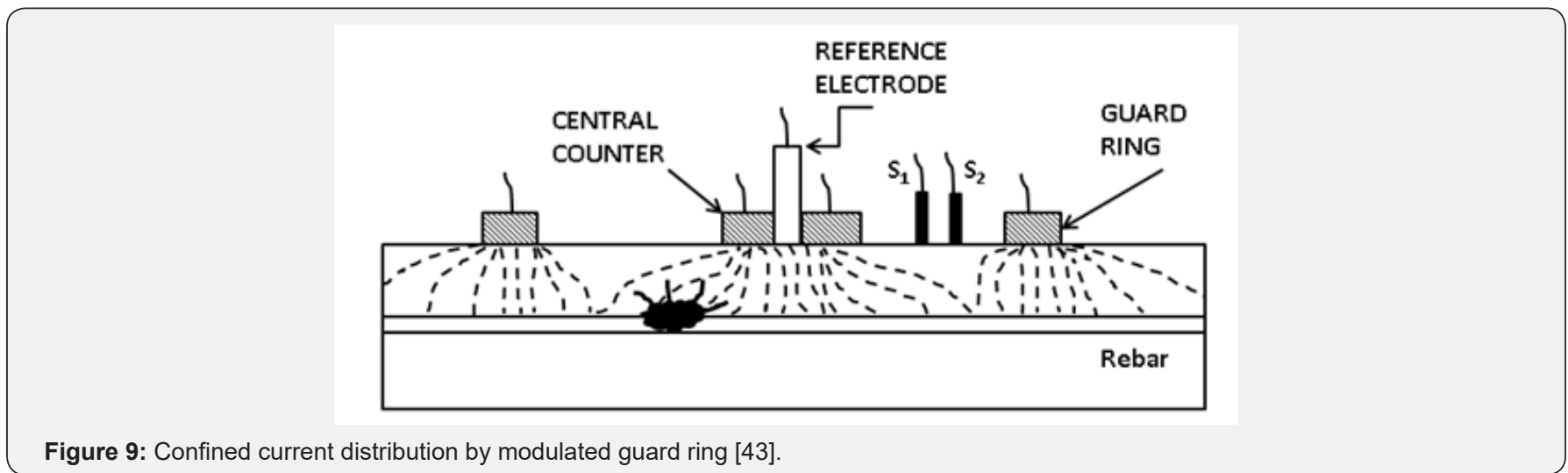

The greatest problem in obtaining a reliable $R_{p}$ measurement, and the cause for the need of the guard ring technique, is the nonuniform current distribution between the counter electrode and the steel reinforcing in the concrete [44]. Figure 7 shows how the current will be distributed between a small counter electrode and the steel reinforcing when no guard ring is present. This distribution allows for a much larger area of steel to be polarised than the area right beneath the electrodes. This is a particular problem when localised corrosion occurs. It may yield elevated corrosion rates without actually having any corrosion occurring under the area of study (Figure 8). It is because the polarization current is confined with a guard ring electrode. The confining effect ensures that the critical length of steel that the reference electrode is exposed to is equal to the length of contact of the reference electrode itself. Figure 9 depicts the ideal current distribution when a modulated guard ring electrode is used.

Potentiodynamic polarization curves (PPC): The change of electrical potential measurement of a system is described by

the PPC. In electrochemical corrosion testing, this term is often used in describing the polarization methods. It is a laboratorybased corrosion-measuring technique which helps prove valuable information regarding corrosion mechanism, rate and probability in selected environments [45].

Electrochemical Impedance Spectroscopy (EIS): Electrochemical impedance spectroscopy (EIS) is a corrosion measuring technique that works in the frequency domain. It postulates that an electrochemical interface, as found on the surface of corroding steel reinforcing can be interpreted as a combination of electrical circuit elements such as resistance, capacitance and inductance. EIS has many advantages in comparison with other electrochemical techniques. During EIS experiments, an alternating voltage is applied to the elements and the resulting current is computed using Ohm's law. Therefore, it is a non-destructive method for the evaluation of a wide range of materials, including coatings, anodized films and corrosion inhibitors. It can also provide detailed information of the 
systems under examination; parameters such as corrosion rate, electrochemical mechanisms and reaction kinetics and detection of localized corrosion can all be determined from these data [46]. This method is still in a development phase, but research has suggested that it gives a better insight into the corrosion process. It is stated that smaller interpretations are necessary to obtain results from EIS than for the polarisation resistance technique [39]. However, the application of EIS for on-site measurements is still very complex and not feasible [43].

\section{Transient techniques}

This method includes techniques such as the galvanostatic pulse technique (GPT) also called potentiostatic method and Coulostatic method. These methods work in the time domain and may be preferred because of the slow steel/concrete interface reactions [39]. The GPT is similar to the polarisation technique, however, a small current is applied to the reinforcing steel and the transient potential is then recorded. Typically, a known amount of small current $(10-20 \mathrm{~mA})$ is injected into the reinforced concrete for a certain amount of time $(<10 \mathrm{mS})$, and then potential decay is observed for a few seconds. A Randles equivalent circuit shown in Figure 10 describes the potential decay due to corrosion of steel in concrete [47]. A Randles circuit entails an active electrolyte resistance $\left(R_{\Omega}\right)$ in series with the parallel combination of the double layer capacitance $(C)$ and an impedance of a faradic reaction. This model can be used to calculate the Polarization resistance $\left(R_{p}\right)$.

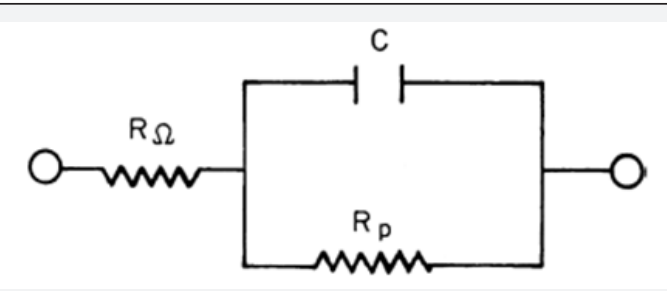

Figure 10: Randles equivalent circuit used to explain the reaction of a steel bar to the electrical signal [47].

$$
\eta_{T}=\Delta I R_{\Omega}+\Delta I R_{p}\left(\exp \left(\frac{-t}{\tau_{c}}\right)\right)
$$

Where $\eta_{T}$ is the total potential change in the working electrode (WE), $\Delta I R_{\Omega}$ is the ohmic drop between the WE and the reference electrode (RE) in the concrete, $\Delta I R_{p}$ is the effective polarisation at charging time, $R p$ is the polarisation resistance of the rebar, and $\tau_{c}$ is the Coulostatic time constant.

The moment current is disturbed, the charge attained by the interfacial layer also called double layer (it refers to two parallel layers of charge surrounding the object), is gradually used in the corrosion reaction. This is because the electrode potential immediately loses the ohmic drop $\left(\Delta I R_{\Omega}\right)$ contribution, and its measurement expresses its actual polarisation. So, during corrosion testing, if no further current is applied to the steel bar, the potential decays can be represented exponentially with time as follows:

$$
\eta_{t}=\eta_{0} \exp \left(\frac{-t}{\tau_{c}}\right)
$$

Where $\eta_{T}$ is the potential shift $(\Delta E)$ at time $t$ and $\eta_{0}$ is the initial potential shift. Polarization resistance $R_{p}$ is then obtained from the time constant $\left(\tau_{c}\right)$ and interfacial $C$ as follows:

$$
\begin{gathered}
R_{p}=\frac{\tau_{c}}{C} \\
C=\frac{q_{s}}{A \eta_{0}} \\
q_{s}=\Delta \dot{x} \Delta t \\
I_{\text {corr }}=\frac{B}{R_{p}} \\
V_{\text {corr }}=0.0116 I_{\text {corr }}
\end{gathered}
$$

Where $q s$ is the amount of charge, $\Delta i$ is the amount of current sent, $\Delta t$ is the pulse duration. $\eta_{0}$ and $\tau_{c}$ values can be determined by drawing an exponential function fitted to the perturbation $(\mathrm{mV})$ vs time (sec) curve. $A$ is the steel surface area $\left(\pi d_{s} L_{s}\right)$ and $B$ is the Stern-Geary constant varying from 26 to $52 \mathrm{mV}$ depending on the passive and active corrosion. Andrade \& Alonso [43], Gonzalez et al. [47], Glass [48], and Paul \& van Zijl [49] broadly explained this corrosion rate measuring technique.

Due to the corrosion in steel bars, consequences such as loss of rebar tensile resistance and pitting depths from this observation were then compared with the experimental outcomes. In this regard, Eqs (4.11), (4.12) and (4.13) estimate uniformly corroded depth $\left(d_{c}\right)$ with time, estimate mass loss with time $m_{c}(t)$ and change in rebar yield resistance due to cross section reduction $\left(D F_{y}\right)$.

$$
d_{c}(t)=d_{c 0}+\int_{0}^{t} V_{c o r r} d t=d_{c 0}+\sum_{i=1}^{N_{t}} \frac{1}{2}\left(V_{c o r r}+V_{c o r r, i-1}\right)\left(t_{i}-t_{i-1}\right)
$$

$$
\begin{gathered}
m_{c}(t)=\frac{\pi \rho_{s} L_{s}}{4}\left[d_{s}^{2}-\left(d_{s}-2 d_{c}\right)^{2}\right] \\
\Delta F_{y}(t)=\frac{\pi \sigma_{y}}{4}\left[d_{s}-2 d_{c}(t)\right]^{2}
\end{gathered}
$$

In these equations, $d_{c 0}$ is the initial corroded depth, $t_{i}$ corroding period, $\rho_{s}$ is the steel density, $L_{s}$ is the length of steel, $d_{s}$ is the steel diameter and $\sigma_{y}$ is the nominal yield stress of steel.

\section{Concluding remarks}

Corrosion of reinforcement has been widely investigated by researchers in the last 20 to 30 years. Indeed, corrosion is one of the major problems for reinforced concrete structures (RCS). This typically occurs when the steel bars in the concrete are exposed either to chloride or carbonation environment. Chlorides may 


\section{Civil Engineering Research Journal}

permeate into concrete from its ingredients or penetrated from the surrounding chloride laden environment. Carbonation may occur due to the penetration of acidic gases into the concrete. Besides these, there are few more factors, some related to the concrete quality, such as $\mathrm{w} / \mathrm{c}$ ratio, cement content, impurities in the concrete ingredients, presence of surface cracks, etc. Others are related to the external environment such as moisture, oxygen, humidity, temperature, bacterial attack, stray currents, etc., which affect reinforcement corrosion [50,51]. Several ways have been identified for protecting steel bars or delaying corrosion process in concrete such as increase cover depth, improve quality of concrete for ensuring denser microstructure, etc. There are some other protection methods such as using epoxy coating, stainless steel and non-metallic reinforcement.

In this paper, details of corrosion mechanisms, which include initiation and propagation, and the parameters which contribute to the corrosion process, are described. Indeed, it is a difficult task to measure the actual damage in steel due to corrosion. However, using the corrosion measuring techniques described in this paper, it is possible to estimate the possible damage in steel due to corrosion. Apart from the corrosion measuring techniques reported here, techniques such as eddy current testing [52], acoustic emission technique $[53,54]$, etc. are also available to detect and evaluate corrosion and failures of high-strength steel strands. Of course, the results obtained from different methods may be different but they may be sufficient to represent the corrosion damage with acceptable reliability for decision on repair.

\section{References}

1. Shetty MS (2008) Concrete technology: Theory and Practice. S. Chand Publisher, India, pp. 624

2. Natesan M, Smith S, Humphreys K, Kaya Y (2003) The Cement Industry and Global Climate Change: Current and Potential Future Cement Industry $\mathrm{CO}_{2}$ Emissions'. Greenhouse Gas Control Technologies-6th International Conference, Oxford: Pergamon, USA pp. 995-1000.

3. (2000) ISO 15686-1: Building and constructed assets- Service life planning part 1 General principle. Geneva.

4. Li Z, Leung C, Xi Y (2009) Structural renovation in concrete. Book published by Taylor \& Francis, NY, USA

5. Hu J, Cheng X, Li X, Deng P, Wang G (2015) The Coupled Effect of Temperature and Carbonation on the Corrosion of Rebars in the Simulated Concrete Pore Solutions. Journal of Chemistry.

6. Kumar V (1998) Protection of Steel Reinforcement for Concrete: A Review. Corrosion Reviews 16 (4): 317-358.

7. Liu Y, Weyers RE (1998) Modelling the time-to-corrosion cracking in chloride contaminated reinforced concrete structures. ACI Materials Journal 95(6): 675-681.

8. Paul SC, Van Zijl GPAG (2017) Corrosion deterioration of steel in cracked SHCC. International Journal of Concrete Structures and Materials 11(3): 557-572.

9. Van Zijl GPAG, Paul SC (2018) A novel link of the time scale in accelerated chloride-induced corrosion test in reinforced SHC. Construction and Building Materials 167: 15-19.

10. Langford P, Broomfield J (1987) Monitoring the corrosion of reinforcing steel. Construction Repair 1(2): 32-36.

11. Bertolini L, Elsener B, Pedeferri P, Polder RP (2004) Corrosion of Steel in Concrete, WILEY-VCH Verlag GmbH \& Co KGaA, Weinheim.

12. Tutti K (1982) Corrosion of steel in concrete, Swedish Cement and Concrete Research Institute, of CBI research 82-84: 468.

13. Jiang JY, Wang D, Chu HY, Ma H, Liu Y (2017) The Passive Film Growth Mechanism of New Corrosion-Resistant Steel Rebar in Simulated Concrete Pore Solution: Nanometer Structure and Electrochemical Study. Materials 10(4): 412.

14. Leek DS (1991) The passivity of steel in concrete. Quarterly Journal of Engineering Geology 24: 55-66.

15. Hansson CM, Poursace A, Jaffer SJ (2007) Corrosion of reinforcing bars in concrete. R\&D serial No. 3013a, Portland Cement Association, Skokie, Illinois, USA, p. 33.

16. Hansson CM, Poursaee A, Laurent A (2006) Macrocell and microcell corrosion of steel in ordinary Portland cement and high performance concretes. Cement and Concrete Research 36(11): 2098-2102.

17. Andrade C, Gonzalez JA (1978) Quantitative measurements of corrosion rate of reinforcing steels embedded in concrete using polarization resistance measurements, Werkstoffe und Korrosion 29: 515-519.

18. Broomfield JP (2007) Corrosion of steel in concrete understanding, investigating and repair ( $2^{\text {nd }}$ edn). Taylor \& Francis, USA \& Canada.

19. Vennesland $\emptyset$, Gjørv OE (1981) Effect of cracks in submerged concrete sea structures on steel corrosion. Material Performance 20: 49-51.

20. Okada K, Miyagawa T (1989) Chloride Corrosion of Reinforcing Steel in Cracked Concrete, ACI, SP-65. In Performance of Concrete in Marine Environment, Detroit, Michigan, pp. 237-254.

21. Makita M, Mory Y, Katawaki K (1989) Marine corrosion behaviour of reinforced concrete exposed at Tokyo Bay, ACI, SP-65, In Performance of Concrete in Marine Environment, Detroit, Michigan, pp. 271-290.

22. Dong ZH, Shi W, Guo XP (2011) Initiation and repassivation of pitting corrosion of carbon steel in carbonated concrete pore solution. Corrosion Science 53(4): 1322-1330.

23. Zhao X, Chen C, Xu W, Zhu Q Ge C (2016) Evaluation of long-term corrosion durability and self-healing ability of scratched coating systems on carbon steel in a marine environment. Chinese Journal of Oceanology and Limnology, p. 1-14.

24. Wang Y, Fang G, Ding W, Han N, Xing F, et al. (2015) Self-immunity microcapsules for corrosion protection of steel bar in reinforced concrete, Scientific Reports p. 5.

25. Mihashi H, SFU, Ahmed, Kobayakawa A (2011) Corrosion of reinforcing steel in fibre reinforced cementitious composites. Journal of Advantage Concrete Technology 9(2): 159-167.

26. Rooij MR, Schlangen E, Joseph C (2013) Self-healing phenomena in cement-based materials, State-of-the-Art Report of RILEM Technical Committee 221-SHC, Springer publication.

27. Mohammed TU, Otsuki N, Hamada H, Yamaji T (2002) Chlorideinduced corrosion of steel bars in concrete with presence of gap at steel-concrete. ACI Materials Journal 99(2): 149-156.

28. Hansen EJ, Saouma VE (1999) Numerical Simulation of Reinforced Concrete Deterioration-Part I: Chloride Diffusion. ACI Materials Journal 96(2): 173-181.

29. Fib Bulletin 3 (1999) Structural concrete- Textbook on behaviour, design and performance (vol 3).

30. Mendoza DN, Tiburci CG, Hervert HL, Mendez RC, Castro-Borges P (2012) Identifying Factors Influencing the Corrosion Rate of Steel Using 


\section{Civil Engineering Research Journal}

Nonparametric Statistics, International Journal of Electrochemical Science 7: 6343-6352.

31. Paul SC (2015) The role of cracks and chlorides in corrosion of reinforced strain hardening cement-based composite (R/SHCC), PhD thesis, Stellenbosch University, South Africa.

32. Carino NJ, Clifton JR (1995) Prediction of cracking in reinforced concrete structures, Building and Fire Research Laboratory National Institute of Standards and Technology (NISTIR 5634). US Department of Commerce, Gaithersburg, MD 20899.

33. (2009) Cement Concrete \& Aggregates Australia. Chloride resistance of concrete, p. 37.

34. Czarnecki L, Loukowski P, Garbacz A, Chimielewska B (2010) Corrosion of construction materials, CHEMIK 64(9): 573-582.

35. Song G, Shayan A (1998) Corrosion of steel in concrete: causes, detection and prediction, A state-of-the-art review, ARRB Transport Research Ltd, Review Report 4: 53-77.

36. ASTM C876-15 (2015) Standard Test Method for Corrosion Potentials of Uncoated Reinforcing Steel in Concrete. ASTM International, West Conshohocken, PA.

37. Arup H (1983) Corrosion of reinforcement in concrete construction, Page et al (eds), The royal society of chemistry, London, UK, pp. 151.

38. Gu P, Beaudoin JJ (1998) Obtaining effective half-cell potentia measurements in reinforced concrete structures. National Research Council of Canada, Construction Technology Update No.1, ISSN 1206 1220 .

39. Montemor MF, Simoes AMP, Ferreira MGS (2003) Chloride-induced corrosion on reinforcing steel: from the fundamental to the monitoring techniques. Cement \& Concrete Composite 25(4-5): 491-502.

40. Cusson D, Qian S (2009) Ten-year field evaluation of corrosion inhibiting systems in concrete bridge barrier walls. ACI Materials Journal 106(3): 291-300.

41. Andrade C, Alonso C, Gulikers J, Polder R, Cigna R, et al. (2004) Test methods for on-site corrosion rate measurement of steel reinforcement in concrete by means of the polarization resistance method, Materials and Structures 37: 623-643.

42. Mansfeld F (1976) The Polarization Resistance Technique for Measuring Corrosion Currents, Fontana MG, et al. (eds.), Advances in Corrosion Science and Technology, New York, USA pp. 163-262.
43. Andrade C, Alonso C (2004) Test Methods for on-site corrosion rate of steel reinforcing in concrete be means of the polarization resistance method. Materials and Structures 37: 623-643.

44. Wojtas $\mathrm{H}$ (2004) Determination of corrosion rate of reinforcement with a modulated guard ring electrode analysis of errors due to lateral current distribution. Corrosion Science 46(7): 1621-1632.

45.ASTM G61-86 (2014) Standard Test Method for Conducting Cyclic Potentiodynamic Polarization Measurements for Localized Corrosion Susceptibility of Iron-, Nickel-, or Cobalt-Based Alloys. ASTM International, West Conshohocken, PA.

46. Hamdy AS, El-Shenawy E, El-Bitar T (2006) Electrochemical Impedance Spectroscopy Study of the Corrosion Behavior of Some Niobium Bearing Stainless Steels in 3.5\% NaCl. International Journal of Electrochemical Science 1: 171-180.

47. Gonzalez JA, Cobo A, Gonzalez MN, Feliu S (2001) On-site determination of corrosion rate in reinforced concrete structures by use of galvanostatic pulses. Corrosion Science 43(4): 611-625.

48. Glass GK (1995) An assessment of the coulostatic method applied to the corrosion of steel in concrete. Corrosion Science 37(4): 597-605.

49. Paul SC, van Zijl GPAG (2014) Crack formation and chloride induced corrosion in reinforced strain hardening cement-based composites (R/SHCC). Journal of Advanced Concrete Technology 12: 340-351.

50. Ahmad S (2003) Reinforcement corrosion in concrete structures, its monitoring and service life prediction-a review, Cement and Concrete Composite 25(4-5): 459-471.

51. Paul SC, Babafemi AJ (2018) A Review of Mechanical and Durability Properties of Strain Hardening Cement-Based Composite (SHCC). Journal of Sustainable Cement-Based Materials 7(1): 57-78.

52. De Alcantara NP, Da Silva FM, Guimarães MT, Pereira MD (2015) Corrosion Assessment of Steel Bars Used in Reinforced Concrete Structures by Means of Eddy Current Testing. Sensors 16(1): 15.

53. Li Z, Li F, Zdunek A, Landis E, Shah SP (1998) Application of Acoustic Emission Technique to Detection of Rebar Corrosion in Concrete. ACI Materials Journal 95(1): 68-81.

54. Djeddi L, Khelif R, Benmedakhene S, Favergeon J (2013) Reliability of Acoustic Emission as a Technique to Detect Corrosion and Stress Corrosion Cracking on Prestressing Steel Strands. International Journal of Electrochemical Science 8: 8356-8370.

\section{Your next submission with Juniper Publishers will reach you the below assets}

- Quality Editorial service

- Swift Peer Review

- Reprints availability

- E-prints Service

- Manuscript Podcast for convenient understanding

- Global attainment for your research

- Manuscript accessibility in different formats

( Pdf, E-pub, Full Text, Audio)

- Unceasing customer service

Track the below URL for one-step submission https://juniperpublishers.com/online-submission.php 